\title{
THE EFFECT OF TAX PLANNING AND DEFERRED TAX EXPENSE TO EARNINGS MANAGEMENT
}

\author{
Riaty Handayani ${ }^{1}$ \\ ${ }^{1}$ Universitas Mercu Buana \\ Giawan Nur Fitria ${ }^{2}$ \\ ${ }^{2}$ Universitas Mercu Buana \\ Erwin Indriyanto ${ }^{3}$ \\ ${ }^{3}$ Univeristas Nasional \\ Molina $^{4}$ \\ ${ }^{4}$ Universitas Nasional
}

Article DOI: https://doi.org/10.36713/epra3394

\begin{abstract}
This research aims to determine the effect of tax planning and deferred tax expense on earnings management. Tax planning and deferred tax expense is one of strategy for companies to maximize revenue. This study used a food and beverage sub sector manufacturing company for 5 years of observation, namely from 2013-2017. This research used multiple regressions with SPSS 23 for test data.

The result that tax planning has no significant effect on earnings management. In addition, deferred tax expense also has a positive and significant effect on earnings management.

KEYWORDS: tax planning, deferred tax expense, earnings management.
\end{abstract}

\section{INTRODUCTION}

Good financial management must be able to guarantee the sustainability of the company's business. Corporate management is responsible for managing finances in accordance with the principles of accountability. Information about earnings is an important element used by users of financial statements, both internal and external parties for decision making. Earnings information must reflect the company's actual economic and financial situation, but in the reality it is often earnings management reflect not real. Management's actions manipulate financial statements by reporting increased profits indicating the existence of earnings management practices by the company.

According to Sulistyanto (2008: 48) earnings management is an effort by managers to influence information in financial statements with the aim of tricking stakeholders who want to know the company's performance and condition. The factor that can influence earnings management is tax planning. Namely by regulating reported profits to fiscal, so that the tax paid by the company is smaller than it should be paid. For a company, tax is a cost element that reduces 
the company's profit, because the higher the tax that is borne by a company means the smaller the profit the company will get, so that a tendency arises to minimize tax payments. Efforts to minimize taxes are often referred to as tax planning or tax sheltering (Suandy, 2011).

The tax planning of the company have a risk for companies such as tax penalties or administrative sanctions in the future due to the income tax calculation errors especially with regard to the regulation of the expired tax collection in Indonesia for 5 years (Tarmidi\& Murwaningsari, 2019). Several previous studies have examined the effect of tax planning on earnings management, including Negara and Saputra (2017), Pratita (2017), Yunila and Aryati (2018), Lestari et al (2018), and Prasetryo (2019). They examined the effect of tax planning on earnings management with the results that tax planning has a significant effect on earnings management. Another study from Warsono (2017), Mudjiyanti (2018), Mulatsih et al (2019) dan Purnamasari (2019) have result that tax planning has influenced to earnings management in manufacture industry. However, on the other hand, other researchers such as Aditama and Purwaningsih (2014), Sylvia et al (2016), Warhani \& Santi (2018) examine the effect of tax planning on earnings management with different result that tax planning has no effect on earnings management. Their study result supported by another study from Widiatmoko \& Mayang sari (2016), Mulyani et al (2018) and Bunaca \& Nurdayadi (2019). Our study expected to fill this research gap. Our study examine the effect of tax planning to earnings management.

Companies in Indonesia in preparing financial statements are guided by the Statement of Financial Accounting Standards (PSAK) and Tax Regulations. The difference between accounting and taxation financial statements is because in the preparation of financial statements, accounting standards provide more flexibility for management in determining accounting principles and estimates than are allowed according to tax regulations. The greater motivation of management to conduct earnings management will lead to greater differences between accounting earnings and taxation profits (Mills and Newberry, 2001 in Irreza and Yulianti, 2010). The difference between accounting profit and tax (fiscal) profit will result in deferred tax burden that must be paid by the company in the coming period as a result of the recognition of deferred tax liabilities or assets. Deferred tax expense allows a company to exploit loopholes in engineering its financial statements. Deferred tax expense explains that a deferred tax expense can influence a company to manage earnings because the deferred tax expense can reduce the level of profit in the company.

The effect of deferred tax expense on earnings management has also been studied by several previous researchers. Negara and Saputra (2017), Pratita (2017) As well as Rahayu and Machdar (2019), the results of their study indicate that deferred tax expense has a significant effect on earnings management. A deferred tax expenses to earnings management have been research by Wang (2016), Warsono (2017), Bunaca \& Nurdayadi (2019), and Purnamasari (2019) have same result that deferred tax expense effect on earnings management. On the other hand, some researchers through the results of their research explain that deferred tax expense has no influence on earnings management such as Timuriana and Muhammad (2015), Sylvia et al (2016), Yunila and Aryati (2018), Mudjiyanti (2018), Hakim (2019), Mulatsih et al and Prasetyo et al (2019).

Our study contributes to give more literature about the effect of tax planning and deferred tax to earnings management. Based on the background description and inconsistency of the results of previous studies, we felt the need to conduct research on tax planning and deferred tax expense on earnings management.

\section{LITERATURE REVIEW AND HYPOTHESES DEVELOPMENT Earning Management}

Earnings information as part of financial statements is often the target of engineering through management opportunistic actions to maximize satisfaction, but can be detrimental to shareholders or investors. These opportunistic actions are carried out by choosing certain accounting policies, so that the company's profits can be adjusted according to their wishes, management behavior to regulate profits in accordance with these desires is known as management.

Belkoui in Achmad Daengs (2014: 201) states:

"Earnings management is the ability to manipulate the choices available and take the right choices to reach the expected profit level. This is one of the striking examples of designed accounting ".

Based on some previous experts' understanding, it can be concluded that earnings management is done intentionally, within the limits to lead to a desired profit level. This action is the manager's action to increase (reduce) the current reported earnings of the unit for which the manager is 
responsible, without causing an increase (decrease) in the long-term economic profitability of the unit.

\section{TAX PLANNING}

According to Suandy (2011: 6) understanding of tax planning is:

"Tax planning is a first step in carrying out tax management. At this stage, collection and research of taxation regulations is carried out in order to select the type of austerity measures to be taken. In general, the emphasis of tax planning is to minimize tax obligations $"$.

The definition of tax planning proposed by Anwar (2013: 18) is as follows:

"Tax planning is the process of organizing business taxpayers of individuals and business entities in such a way by utilizing various possibilities loopholes that can be taken by companies in the corridor of tax regulations (loopholes), so that companies can pay taxes in a minimum amount".

So, basically tax planning is a taxpayer effort to achieve efficient payment of tax burden by minimizing payment of tax burden by not violating the provisions that have been set in tax regulations or tax laws.

\section{DEFERRED TAX EXPENSE}

According to Harnanto (2011: 115) the definition of deferred tax expense is:

"Expenses arising from temporary differences between accounting earnings (earnings in financial statements for external parties) and fiscal profits (earnings used as a basis for calculating taxes)".

According to Waluyo (2012: 272), the definition of deferred tax expense is as follows:

"The amount of deferred tax expenses (income) arising from the recognition of deferred tax liabilities or assets".

Based on the definition of deferred tax expense above, it can be concluded that deferred tax expense is an expense arising from the temporary difference between accounting profit and fiscal profit where income according to commercial accounting is greater than fiscal accounting and expenditure according to commercial accounting is smaller than fiscal accounting.

\section{EFFECT OF TAX PLANNING ON PROFIT MANAGEMENT}

To be able to minimize tax obligations, various methods can be carried out, both those that still meet the tax provisions (lawful) and those that violate tax regulations (unlawful), such as tax avoidance and tax evasion. Tax planning generally always starts with convincing whether a transaction or event has a taxation impact. If the event has a tax impact, can the impact be exempted or reduced by the tax amount? Furthermore, whether the tax payment can be postponed. One of the tax plans is by regulating how much profit is reported, so that it is included in the indication of earnings management practices.

Negara and Saputra (2017), Pratita (2017), Yunila and Aryati (2018), Lestari et al (2018), and Prasetryo (2019). They examined the effect of tax planning on earnings management with the results of research that tax planning has a significant effect on earnings management. Based on the description above, it can be concluded temporarily that tax planning has a significant effect on earnings management.

H1: Tax Planning Has a Positive Impact on Earnings Management

\section{EFFECTS OF DEFERRED TAX EXPENSES ON PROFIT MANAGEMENT}

According to Djamaludin (2008), the negative difference between accounting profit and fiscal profit results in a negative correction that results in deferred tax expense. A large burden will reduce the level of profits obtained by a company, and vice versa a small burden will increase the level of profits earned by a company. That is what triggers managers to do earnings management by increasing and reducing the amount of deferred tax expense recognized by the income statement. Because basically when the deferred tax burden is large, the profit to be gained by the company will be small.

The effect of deferred tax expense on earnings management has also been studied by several previous researchers. Negara and Saputra (2017), Pratita (2017) As well as Rahayu and Machdar (2019), the results of their study indicate that deferred tax expense has a significant effect on earnings management. Based on the description above, it can be concluded temporarily that the deferred tax expense has a significant effect on earnings management.

H2: Deferred Tax Burden Has a Positive Impact on Earnings Management

\section{RESEARCH METHOD}

This type of research uses content analysis with a quantitative approach. The study was conducted on the website of the food and beverage manufacturing 


\section{EPRA International Journal of Research and Development (IJRD) Volume: 5 | Issue: 6 | June 2020 \\ - Peer Reviewed Journal}

sector companies that went public on the Indonesia Stock Exchange in 2013 - 2017. The dependent variable used is earnings management while the independent variable used is tax planning and deferred tax expense. The research data obtained will be processed and analyse quantitatively and further processed so that it can clarify the picture of the object under study and then from these results can be concluded.

Table 1. Sample Selections

Criteria Total

Total food and beverage sub-sector manufacturing companies listed on the Stock 18 Exchange from $2013-2017$

Food and beverage sub-sector manufacturing companies have not registered an IPO in 2013

The financial statements presented are incomplete during the research year

\begin{tabular}{lc}
\hline Total sample & 11 \\
\hline Firm years & 5 \\
\hline Total Data & 55 \\
\hline
\end{tabular}

Tabel . 2 Operational Variable

\begin{tabular}{|c|c|c|c|c|}
\hline No & Variables & Dimentions & Measurement & Scale \\
\hline 1. & Dependent & Earning Management & $D A_{i t}=T A_{i t} / A_{i t}-N D A_{i t}$ & Ratio \\
\hline 2 & Independent & Perencanaan Pajak & Net Income / EBIT & Ratio \\
\hline 3 & Independent & Deferred Tax Expense & $\begin{array}{c}\text { DTE = Deferred tax } \\
\text { Total asset }\end{array}$ & Ratio \\
\hline 4 & Control & Size & Ln Total Aset & Ratio \\
\hline
\end{tabular}

The method used for hypothesis testing in this study is the panel data method (pooled regression), using data analysis tools in the form of SPSS 23

\section{RESULT AND DISCUSSION Goodness of Fit}

Tabel 3. The Result of Goodness of Fit

\begin{tabular}{|cc|c|c|c|c|c|}
\hline \multicolumn{1}{|c|}{ Model } & Sum of & ANOVA & & \\
& Squares & df & Mean Square & F & Sig. \\
\hline \multirow{2}{*}{1} & Regression & 3.263 & 3 & 1.088 & 7.793 & $.000^{\mathrm{b}}$ \\
& Residual & 7.118 & 51 & .140 & & \\
& Total & 10.380 & 54 & & & \\
\hline
\end{tabular}

a. Dependent Variable: Earning_Management

b. Predictors: (Constant), Size, Deffered_Tax_Expense, Tax_Planning

Based on the results of the F-test in Table 3 above, it shows that the significance result is 0,000 which means below the value of 0.05 . This shows that software. Quantitative methods will be used in this study.
(7)

(0) 


\section{EPRA International Journal of Research and Development (IJRD) \\ Volume: 5 | Issue: 6 | June 2020 \\ - Peer Reviewed Journal}

Table 4. Coefficient Determinant Result

\begin{tabular}{|c|c|c|c|c|c|}
\hline Model & $\mathrm{R}$ & R Square & $\begin{array}{c}\text { Adjusted R } \\
\text { Square }\end{array}$ & $\begin{array}{c}\text { Std. Error of } \\
\text { the Estimate }\end{array}$ & Durbin-Watson \\
\hline 1 & $.561^{\mathrm{a}}$ & .314 & .274 & .373576 & 1.291 \\
\hline
\end{tabular}

a. Predictors: (Constant), Size, Deffered_Tax_Expense, Tax_Planning

b. Dependent Variable: Earning_Management

Based on table 4 above, it can be seen that the $\mathrm{R}$-square value of 0.314 or $31.4 \%$, which means that the independent variable in this study can explain the dependent variable of $31.4 \%$. While the remaining $68.4 \%$ is influenced by other variables.

Table 5.Hypotheses Test Result

Coefficients $^{\mathrm{a}}$

\begin{tabular}{|c|c|c|c|c|c|c|c|c|}
\hline \multirow{2}{*}{\multicolumn{2}{|c|}{ Model }} & \multicolumn{2}{|c|}{$\begin{array}{l}\text { Unstandardized } \\
\text { Coefficients }\end{array}$} & \multirow{2}{*}{$\begin{array}{c}\begin{array}{c}\text { Standardiz } \\
\text { ed } \\
\text { Coefficients }\end{array} \\
\text { Beta } \\
\end{array}$} & \multirow[b]{2}{*}{$\mathbf{t}$} & \multirow[b]{2}{*}{ Sig. } & \multicolumn{2}{|c|}{$\begin{array}{c}\text { Collinearity } \\
\text { Statistics }\end{array}$} \\
\hline & & B & Std. Error & & & & $\begin{array}{c}\text { Toleran } \\
\text { ce }\end{array}$ & VIF \\
\hline \multirow[t]{4}{*}{1} & (Constant) & .514 & .951 & & .541 & .591 & & \\
\hline & Tax_Planning & 1.319 & 1.033 & .178 & 1.277 & .207 & .695 & 1.438 \\
\hline & Deffered_Tax_Expense & 27.801 & 11.543 & .335 & 2.409 & .020 & .696 & 1.436 \\
\hline & Size & -.070 & .034 & -.246 & -2.076 & .043 & .958 & 1.044 \\
\hline
\end{tabular}

a. Dependent Variable: Earning_Management

Based on the results of the hypothesis test above, it can be concluded as follows:

a. Variable tax planning has a significance / probability value of 0.207 which indicates a significance value $>0.05$, so it can be concluded that $\mathrm{H} 1$ is rejected. This shows that variable tax planning has no significant effect on earnings management.

b. The deffered tax expense variable has a significance / probability value of 0.020 which indicates a significance value $<0.05$, so it can be concluded that $\mathrm{H} 1$ is accepted. This shows that the variable deffered tax expense has a significant effect on earnings management.

SIZE is a control variable in this study, which turned out to have a significance / probability value of 0.043 indicating a significance value $<0.05$, so it can be concluded that company size has a significant effect on earnings management.

\section{EFFECTS OF TAX PLANNING ON EARNING MANAGEMENT}

Based on the results of the hypothesis test in table 5, it shows that tax planning has a positive but not significant effect, so it can be interpreted that tax planning has no effect on earnings management. This shows that the tax planning carried out by the sample companies is only used to avoid sanctions that might arise due to the application of taxes that would violate taxation laws. In addition, corporate tax planning activities cause taxable income to be smaller than commercial profits, because tax planning only affects taxable income without affecting commercial profits. Our study support the research of Aditama and Purwaningsih (2014), Sylvia et al (2016), Warhani \& Santi (2018), Mulyani et al (2018), Hakim (2019) and Bunaca \& Nurdayadi (2019). 


\section{EPRA International Journal of Research and Development (IJRD)}

\section{EFFECTS OF DEFERRED TAX EXPENSES ON EARNING MANAGEMENT}

Based on the results of the hypothesis test in table 5 shows that the deferred tax expense has a positive and significant effect on earnings management. This shows that the more an increase in deferred tax expense, the probability of companies to conduct earnings management will also increase. This indicates that the company in the study sample will avoid losses if there is an increase in deferred tax expense by carrying out higher earnings management practices.

The results of this study are support previous research by Negara and Saputra (2017), Pratita (2017), Rahayu \& Machdar (2019), BUnaca \& Nurdayadi (2019) and Purnamasari (2019) with the result that the deferred tax expense has a positive and significant effect on earnings management.

\section{EFFECT OF COMPANY SIZE ON PROFIT MANAGEMENT}

Company size is a control variable in this study. The test results based on table 5.7 show that company size (size) has a positive and significant effect on earnings management. This happens because the larger the company, the greater the company's operating expenses, so as to avoid losses, the company will tend to do earnings management. The results of this study also support research Wardhani and Santi (2018) which explains that company size has a positive and significant effect on earnings management.

\section{CONCLUSION}

Tax planning which is proxied through a tax retention ratio has no significant effect on earnings management. This is because manufacturing companies in the study sample use tax planning activities in order to free the company from sanctions and fines arising from violations of taxation laws. In addition, corporate tax planning activities cause the company's taxable income to be smaller than commercial profits, because tax planning activities only affect taxable income without affecting the company's commercial profits.

Deffered tax expense on the results of this study has a positive and significant effect on earnings management. This can be indicated that manufacturing companies in the study sample tend to do earnings management when the deferred tax burden is higher to avoid losses on financial reporting.

This research still has many limitations, including: testing is only limited to manufacturing companies in the food and beverage sector with 5 years of testing. For further research, it is expected to expand sample testing to all manufacturing companies listed on the Indonesia Stock Exchange.

\section{REFERENCES}

1. Aditama, Ferry dan Purwaningsih, Anna. (2014). Pengaruh Perencanaan Pajak Terhadap Manajemen Laba Pada Perusahaan NonManufaktur Yang terdaftar di Bursa Efek Indonesia. Jurnal MODUS Vol. 26 (1): 33-50 ISSN: 0852-1875

2. Bunaca, Alfian Rocky \& Nurdayadi. The Impact Of Deferred Tax Expense and Tax Planning Toward Earning Management and Profitability. Jurnal Bisnis dan Akuntansi P-ISSN: 1410 - 9875 Vol. 21, No. 2, Des 2019, Hlm. 215-236 E-ISSN: $2656-$ 9124.

3. Jensen, C., \& Meckling. (1976).Theory of the Firm : Managerial Behavior, Agency Cost and Ownership Structure, 3, 305-360. https://doi.org/10.1016/0304-405X(76)90026-X

4. Lestari, et al. (2018). Pengaruh Perencanaan Pajak dan Ukuran Perusahaan Terhadap Manajemen Laba. Jurnal Ilmiah MEA Vol 2. No. 3 SeptemberDesember 2018 E-ISSN: 2621-5306 P-ISSN: 25415255 .

5. Hakim, Lukman and Gian Anugerah Pratama, (2019), "The Influence of the Tax Charges, TaxDefered and Planning, Againt Earnings Management (Case Studies to the Property and Real Estate Listed at the Indonesian Stock Exchange 2016-2018 period)" in International Conference on Economics, Management, and Accounting, KnE Social Sciences, pages 727-743. DOI 10.18502/kss.v3i26.5411

6. Mudjiyanti, Rina. (2018). The Effect of Tax Planning, Ownership Structure, and Deferred Tax Expense on Earning Management. Advances in Social Science, Education and Humanities Research, volume 231. Atlantis press.

7. Mulyani, et al. (2019). The Effect of Tax Planning and Deferred Tax Expense on Earnings Management on Manufacturing Companies Listed In The Indonesia Stock Exchange. The 2nd International Conference on Technology, Education, and Social Science 2018 (The 2nd ICTESS 2018).

8. Mulatsih, et al .(2019). The Effect of Tax Planning, Asset of Deferred Tax, Dferred Tax Expense on Profit Management (Case Study of Manufacturing Companies Listed on the Stock Exchange 20132017 Period). 2nd ICIEBP The 2nd International Conference on Islamic Economics, Business, and Philanthropy (ICIEBP) Theme: "Sustainability and Socio Economic Growth” Volume 2019 


\section{EPRA International Journal of Research and Development (IJRD) Volume: 5 | Issue: 6 | June 2020 \\ - Peer Reviewed Journal}

9. Negara, AA Gede dan Saputra, IGD Dharma.(2017). Pengaruh Perencanaan Pajak dan Beban Pajak Tangguhan Terhadap Manajemen Laba. E-Jurnal Akuntansi Universitas Udayana Vol. 20.3 September 2017: 2045-2072

10. Prasetyo, et al.(2019). Pengaruh Perencanaan Pajak, Beban Pajak Tangguhan dan Kualitas Audit Terhadap Manajemen Laba. Jurnal MODUS Vol 31 (2) : Hal 156 - 171.ISSN: O852-1875/Online: 2549-3787.

11. Pratita, Nissa Arisanty. (2017). Pengaruh Perencanaan Pajak, Beban Pajak Tangguhan dan Akrual Manajemen Laba. Jurnal JOM Fekon Vol. 4 No. 1 (April) 2017.

12. Purnamasari, Dyah. (2019). How The Effect Tax Expenses And Tax Planning OnEarning Management?. International Journal Of Scientific \& Technology Rresearch. Vol. 8, Issue 02, February 2019 ISSN 2277-8616

13. Rahayu, Mira Agustina dan Machdar, Nera Marindah. (2019) Pengaruh Beban Pajak Tangguhan, Aktiva Pajak Tangguhan dan Akrual Terhadap Manajemen Laba Pada Perusahaan Manufaktur yang Terdaftar di Bursa Efek Indonesia. Jurnal Bisnis dan Komunikasi ISSN $2346-4385$.

14. Setiawan, Budi dan Harnovinsah. (2016). Pengaruh Beban Pajak tangguhan, Profitabilitas, dan Perencanaan Pajak Terhadap Manajemen Laba. Jurnal Manajemen dan Akuntansi No. ISSN 25285599 No. ISSN Online: 2614-3291.

15. Sundvick, Dennis. (2017). A review of earnings management in private firms in response to tax rate changes. Nordic Tax J. 2017; 1:151-161.

16. Sylvia et al. (2016). Pengaruh Beban Pajak Tangguhan, Perencanaan Pajak dan Debt To Equity Ratio Terhadap Praktik Manajemen Laba. Jurnal Informasi, Perpajakan, Akuntansi dan Keuangan Publik. Vol. 11 No. 2 Juli 2016. Hal 105120.

17. Tarmidi, D., \& Murwaningsari, E. (2019). The Influence of Earnings Management and Tax Planning on Firm Value with Audit Quality as Moderating Variable, 10(4), 49-58. https://doi.org/10.7176/RJFA

18. Timuriana, Tiara dan Muhammad, Rezwan Rizki.(2015). Pengaruh Aset Pajak Tangguhan dan Beban Pajak Tangguhan Terhadap Manajemen Laba. Jurnal Ilmiah Akuntansi Fakultas Ekonomi Universitas Pakuan Volume 1 No. 2 Tahun 2015 Hal 12-20.

19. Wang, Ying., Butterfield, Scott \& Campbell, Michael. (2016). Deferred Tax Items as Earnings Management Indicators. International Management Review. Vol. 12 No. 22016.

20. Wardani, Dewi Kusuma dan Santi, Desida Kurnia.(2018). Pengaruh Tax Planning, Ukuran
Perusahaan, Corporate Social Resposnbility terhadap Manajemen Laba. Jurnal Akuntansi Vol, 6 No. 1 Juni 2018.

21. Warsono. (2017). Deferred Tax Assets and Deferred Tax Expense Against Tax Planning Profit Management. Shirkah Journal of Economics and Business ISSN: 2503-4235 (p); 2503-4243 (e).

22. Widiatmoko, Jacobus; Mayangsari, Ika. (2016). The Impact of Deffered Tax Assets, Discretionary Accrual, Leverage, Company Size and Tax Planning on Earning Management Practices. Jurnal Dinamika Manajemen, 7 (1) 2016, 22 31http://jdm.unnes.ac.id

23. Yunila, Felismina dan Aryati, Titik.( 2018). Pengaruh Perencanaan Pajak dan Pajak Tangguhan Terhadap Manajemen Laba dengan Kualitas Audit sebagai Variabel Moderasi. Seminar Nasional Cendikiawan ke 4 Tahun 2018. ISSN : $2460-8696$ 